\title{
Social Networks as Zones of Digital Personality Construction: Current Problems and Prospects
}

\section{Las redes sociales como zonas de construcción de la personalidad digital: problemas actuales y perspectivas}

\author{
Izabella D. Belonovskaya* \\ Doctor of Education, Professor of the Department of Technology of Mechanical Engineering, Metalworking \\ Machines and Complexes, Orenburg State University, Orenburg, Russia \\ ORCID ID: 0000-0003-0968-8764 \\ Liubov G. Pak \\ Doctor of Education, Professor of the Department of Pedagogics and Sociology, Orenburg State Pedagogical \\ University, Orenburg, Russia \\ ORCID ID: 0000-0001-7321-506X
}

Elvira R. Saitbaeva

Doctor of Education, Professor of the Department of Education Management, Orenburg State Pedagogical University, Orenburg, Russia ORCID ID: 0000-0003-1043-291X

\section{Sergey M. Kolotushkin}

Doctor of Law, Professor of the Center of Studying of Problems of Management and the Organization Executions of Punishments in Criminally-Executive System, of the Research Institute of the Federal Penitentiary Service of Russia, Moscow, Russia ORCID ID: 0000-0002-6223-6110

Irina G. Kartushina

$\mathrm{PhD}$ in Education, Associate Professor of the department of mechanical engineering and technical systems, Immanuel Kant Baltic Federal University, Kaliningrad, Russia.

ORCID ID: 0000-0002-1172-5141

\section{Andrey A. Pavlushin}

Doctor of Technical Sciences, Professor of the Department of Agrotechnology, Machines and Life Safety, Ulyanovsk State Agrarian University named after P.A. Stolypin, Ulyanovsk, Russia

ORCID ID: 0000-0002-7678-2876

\section{Ashot S. Kagosyan}

Doctor of Education, Professor of the Department of Psychology and Pedagogy, Gzhel State University,

Elektroizolyator, Russia

ORCID ID: 0000-0002-0196-4667

Received 08-12-20 Revised 09-30-20

* Correspondence

Email: t251589@mail.ru
Accepted 10-13-20 On line 01-14-21

\section{Citation:}

Izabella D. Belonovskaya, Liubov G. Pak, Elvira R. Saitbaeva, Sergey M. Kolotushkin, Irina G. Kartushina, Andrey A. Pavlushin, Ashot S. Kagosyan. (2021). Social Networks as Zones of Digital Personality Construction: Current Problems and Prospects. Propósitos y Representaciones, $\quad$ 9(SPE1), $1224 . \quad$ Do: http://dx.doi.org/10.20511/pyr2021.v9nSPE1.e 1224 


\section{Summary}

At present, the Internet and its mediated communication are an integral part of everyday life and social networks are becoming the main platform for self-presentation these days. The main tool for such self-expression in social networks is the selfie. The rapid rise in the popularity of selfies suggests that the very practices of self-representation are undergoing a major historical transformation. Research purpose is to study the features of selfies construction. Research methods: as a research method, a questionnaire survey was used as a method that allows quickly and effectively to investigate the features of using selfies as a way of constructing a digital personality. Research results: the article considers the forms of body control in social networks in the practice of constructing selfies. Research novelty and originality lies in the fact that for the first time the practice of selfies as a way of constructing a digital personality is considered. It is shown that selfidentification is based on how the body is evaluated, and not on what it is actually. It is revealed that the body has become a carrier of meaning and a platform for communication with feedback, and the Internet, which has become the main repository of global data sets, has assumed the role of this communication control over the body. It is determined that in understanding the essence of the selfie phenomenon, there are two points of view: the selfie, as a continuation of the tradition of self-portrait and the selfie, as a special unique phenomenon associated to a greater extent with network media content. It is revealed that the main motive of self-presentation is the desire to be socially approved, to get the highest rating and the most flattering or loud comment. It is revealed that the hashtag is one of the structural elements of the selfie, through which the process of constructing the image is carried out. It is shown that an important motive for constructing a selfie is the user's need for a certain visual statement, self-expression. It is determined that in the production of selfies, the user is often guided by fashion trends and ready-made templates, which means that by regulating the real body in space, a successful representation of the digital body in the network is formed. The practical significance of the data obtained in this work lies in their use in social psychology, age psychology, marketing, as well as for further theoretical development of this issue.

Keywords: selfie, internet, internet practice, internet space.

\section{Resumen}

En la actualidad, Internet y su comunicación mediada son parte integral de la vida cotidiana y las redes sociales se están convirtiendo en la principal plataforma de autopresentación en estos días. La principal herramienta para tal autoexpresión en las redes sociales es el selfie. El rápido aumento de la popularidad de las selfies sugiere que las mismas prácticas de autorrepresentación están experimentando una importante transformación histórica. El propósito de la investigación es estudiar las características de la construcción de selfies. Métodos de investigación: como método de investigación, se utilizó una encuesta por cuestionario como método que permite investigar de manera rápida y efectiva las características del uso de selfies como forma de construir una personalidad digital. Resultados de la investigación: el artículo considera las formas de control corporal en las redes sociales en la práctica de la construcción de selfies. La novedad y originalidad de la investigación radica en que por primera vez se considera la práctica de los selfies como forma de construir una personalidad digital. Se muestra que la autoidentificación se basa en cómo se evalúa el cuerpo y no en lo que es en realidad. Se revela que el cuerpo se ha convertido en un portador de significado y una plataforma de comunicación con retroalimentación, e Internet, que se ha convertido en el principal repositorio de conjuntos de datos globales, ha asumido el papel de este control comunicativo sobre el cuerpo. Se determina que en la comprensión de la esencia del fenómeno selfie, existen dos puntos de vista: el selfie, como continuación de la tradición del autorretrato y el selfie, como un fenómeno especial único asociado en mayor medida a los medios de comunicación de la red. contenido. Se revela que el motivo principal de la autopresentación es el deseo de ser aprobado socialmente, de obtener la calificación más alta y el comentario más halagador o ruidoso. Se revela que el hashtag es uno de los elementos estructurales del selfie, a través del cual se lleva a cabo el proceso de construcción de la imagen. Se muestra que un motivo importante para construir una selfie es la necesidad del usuario de una determinada declaración visual, la autoexpresión. Se determina que en la producción de selfies, el usuario a menudo se guía por las tendencias de la moda y las plantillas prefabricadas, lo que significa que al regular el cuerpo real en 
el espacio, se forma una representación exitosa del cuerpo digital en la red. La trascendencia práctica de los datos obtenidos en este trabajo radica en su uso en psicología social, psicología de la edad, marketing, así como para un mayor desarrollo teórico de este tema.

Palabras clave: selfie, internet, práctica en internet, espacio en internet.

\section{Introduction}

The selfie seems to be a new subject of research, which, on the one hand, leads to new topics and expands the empirical available photographic material, and on the other - challenges the research experience, since the scientist is faced with an incomparable volume of visual text that needs to be filtered out when starting research (Baudrillard, 2006; Castells, 2000). Referring to the selfie as a typical representative of self-portrait photography, it should be noted, however, a number of its obvious technological advantages. One of them is the ability to control the angle, lighting, and objects in the frame independently (Bobyreva et al., 2019). Auto-capture mode allows you to monitor and adjust the entire process interactively. Digital photography allows you to take a huge number of pictures and immediately evaluate, edit or delete them. In addition to the mobile device itself, the further use of these photos can be facilitated by special applications of such networks as Facebook, Vkontakte and Instagram. Selfies should be appropriate in the environment of users of the relevant social network and correspond to the standards of attractiveness. Such standards initiate the process of monitoring the body in photos (Grinkova, 2015; Pogontseva, 2013b). An important feature of the selfie production process is the practice of evaluation, during which the construction of the photo is carried out according to conditional ideals. The object of improvement can be something from the elementary details of appearance: lush hair, thinness, fashionable clothes, or from conceptual ideas: context, emotions, angle and number of participants in the photo. A beautiful body that has gained the maximum number of approvals is a tool for meeting the need for recognition, respect, creativity, preserving the author's image, forming a comfortable profile for the author. In the case of social networks, this evaluation criterion is the appearance and visual presentability. Often, a conscious violation of generally accepted aesthetic standards only confirms such an increased attitude to the body. Not following the mainstream only creates new turns of it (Geertz, 2004; Lipman, 2004; Lacostina, 2009).

Thanks to the study of the new phenomenon of the decade - the selfie-it is possible to improve the understanding of modern social processes mediated by technology and mass culture qualitatively. These processes transform a person's physicality through social and individual evaluation and control of the body. Every year this fact becomes more and more indisputable.

\section{Literature Review}

At present, the Internet and its mediated communication are an integral part of everyday life. As a special communication medium, the Internet is a sphere of self-representation that did not exist before (Baranova et al., 2020). Thus, the Internet brings new ways of communication, new patterns of behavior and forms of identity existence. With the development of the digital picture of the world, the formation of a digital personality also takes place (McLuhan, 2007; Savchuk, 2013; Bezbogova, 2016; Veretekhina et al., 2017; Cherdymova et al., 2019; Bayanova et al., 2020).

The discourse and visual component reflect the life of a person with a special specificity, which indicates the formation of new forms of identity. This digital identity is distinguished by its discursivity, hyper-textuality, and the transgression of corporeality into binary code. The emergence of Internet communication provoked a total change in the very nature of the text. The text on the web is equated with the person who writes it, completely reflecting him/her, realizing his/her basic desire for self-expression and creativity through online correspondence. Corporeality tends to selfdiscover itself in the digital space indirectly through it.

Various sciences for a long time did not consider the body as a subject of independent sociopsychological analysis (Apasova, 2008; Anderson, 2001; Cherdymova, 2016; Berger \& Lukman, 
1995; Labunskaya, 2010). If the body was conceptualized, it was as something external to the acting subject, an object of control and overcoming. Only postmodern criticism raised the problem of studying the body. By challenging the classical understanding of the mind as an instrument of emancipation, postmodern criticism engenders an interest in the body as the key to opposing the instrumental mind, but also as one of the objects of everyday life colonized by the social mind (Sohan, 2008; Sorokoumova \& Cherdymova, 2020; Sorokoumova et al., 2020; Drozdova, 2013; Reznichenko et al., 2018; ). The body is not only a biological phenomenon, but also a social one, so one aspect of sociality is control over it. Postmodernist theorists, who connect its discovery as such with the era of Modern times, raised the question of the body as an object of power practices. It is then that there is a widespread appearance of signs of close supervision and attention to the body: the body as an object of manipulation, formation, training, submission, improvement - that is, an obedient body. Thus, it always becomes the object of the application of power practices. Meanwhile, technology is becoming more expansive, penetrating from the surface of the body into the depths. Their intention is to deconstruct, recode the body, adjust its parameters, and artificially reproduce it like a product: the body is a constructor (Surova, 2010; Huntington, 2003; Konfederat, 2012; Pogontseva, 2013a).

Thus, if the disciplinary society, with its ranking and closure of time and space in order to subordinate and control obedient bodies, has created a fragmentary body, the individual parts of which and all its totality are prescribed a certain position and action, then with the interiorization of normativity in the control society, the body becomes an object of social construction. The norms of insufficient or excessive weight, healthy or unhealthy condition, the purity of the skin, the presence or absence of hair determine the coordinates of a good, beautiful body. These standards are popularized through media channels - mass media, cinema, television, the Internet - and are supported in society, constantly updating themselves not only in discourse, but also in everyday practices of body care, weight control and health, aesthetic medicine (Shapinskaya, 2012; Andreeva, 2001; Glinchikova, 2002; Bourdieu, 2002). The body is given meaning: now it is an indicator of the social status of a person, an instrument of visual utterance, the values of which are transmitted to society and receive feedback as an assessment and recommendations for further construction.

\section{Materials and Methods}

The transfer of large-scale arrays of information to the Internet also provoked the transfer of social activity to the Network. The phenomenon of social networks is attracting more and more attention from the audience: visiting social networks in recent years has become universal and has become the main reason for using the Internet.

The empirical study was conducted in several stages.

At the first stage, a sample and a platform for research were formed. The sample was made up of students using social networks. The platform of this research was social networks, specifically social networks Instagram, Vkontakte.

At the second stage of the study, the questionnaire units were formulated and the questionnaire questions were developed. The logic of the study also assumed the following research questions:

What are the practices of designing selfies?

What are the rules for designing selfies?

What is the nature of the involvement of social media users in the practice of photographing selfies?

What is the frequency of selfie posts?

What are the reasons for evaluating the success and failure of selfies?

Do you feel involved in the construction of a digital identity through selfies?

What is the possible reaction of users to the assessment by the control subjects?

What are the practices of controlling the body represented in social networks?

What are the manifestations of body control practices presented on social networks?

What are the subjects of control over the body represented by social networks? 
What are the channels for evaluating and monitoring the body by the subjects of control?

At the third stage of the study, the results obtained were analyzed, conclusions were formulated, and ways of further research were formulated.

\section{Results}

\section{Features of Using Selfie Practices}

The first set of questions was aimed at determining the nature of the involvement of users of social networks in the practice of photographing selfies. The respondents surveyed are $100 \%$ involved in this type of practice. The analysis of the information received on the first set of questions allowed us to draw several conclusions. First, among the respondents, a greater number of informants exclusively refer a face image $(87 \%)$ to the selfie genre. Selfies are rarely taken $(25 \%)$. Only $13 \%$ of informants defined a selfie broadly as an auto-snapshot of themselves, regardless of which part of the body refers to themselves.

At the same time, the indissoluble connection of the image and the text that goes with it is emphasized (57\%). The text serves as an artistic device, additionally focusing on important elements, and putting non-essential ones in the background (87\%). Thanks to it, we can conclude that the hashtag is one of the structural elements of the selfie, through which the process of constructing the image is carried out. Thus, we can say that the selfie implements the tendency to reduce the digital personality partially to the face and head (87\%). It is also worth noting that all respondents, as an integral element of selfies, determine the technically conditioned possibility of monitoring the image in real time thanks to the front camera or monitoring the reflection in the mirror through the display of a mobile device (100\%).

As for the frequency of production and publication of selfies by informants, we can say that all respondents share these processes. For example, the frequency of selfies published can vary from one photo every few months $(16 \%)$ to two or three per day $(84 \%)$, but the frequency of selfie production remains approximately equally high for everyone.

In addition, along with this, there was a tendency for informants to visit social networks Instagram and Vkontakte daily in order to check their profile, to have new ratings and comments, to view the photo feed of subscriptions (98\%). It is worth noting that under the publication informants understand posting photos directly to the photo gallery, but all respondents share their selfies in personal correspondence, both on Instagram and in other social networks (100\%). The motives and goals can be completely different. For example, the approval of the appearance by the near social environment (67\%). Alternatively, compensation for missing emoji (emoticons) to convey mood or nonverbal communication (10\%). This may be an intimate or sexual correspondence (6\%). Also for notifying loved ones about their current state of affairs (2\%).

Modern technologies actually oblige a person not just to be in the information flow, to be aware of events, but also to be represented, visible. The user becomes involved in a large-scale information cycle, and this need may be increasingly transformed as they become involved in this process.

Thus, we can say that social networks really appear as a space of self-presentation, carried out thanks to the possibility of constructing a digital personality. The user's involvement in the public dialogue in the space of social networks implies the mandatory construction of a visual image of himself in the network $(97 \%)$. The analysis of the informants' responses to the first unit of the questionnaire allows us to conclude that the user differentiates the audience into a certain circle of trust $(56 \%)$ and the public (44\%). The circle of trust - close friends, spouses, parents, children-does not need to present themselves in the best possible way, to construct an image of the ideal, successful, attractive self, these people become the recipients of selfies as an element of personal correspondence in the social network (selfies that are not subjected to careful selection and editing, or are exposed to a lesser extent). The public (which also includes the circle of trust) is the audience of self-presentation; it is here that we can talk about the practices of control over the body represented 
in the photo and the rules for constructing selfies in order to form a certain image, the image of a certain social group (100\%).

It should be noted that many of the highlighted features that make up the composition and design of images in the selfie genre are quite controversial. For example, the characteristic protrusion of the lips, almost exceptional joy and the absence of negative emotions in the photo cannot be considered as an integral characteristic of the selfie due to the wide variety of subjects of the pictures, their emotional and semantic saturation. The statement about the specific composition of the selfie and the violation of the proportions of the body and face caused by shooting at arm's length is convincing: the partial absence of one or both hands is really typical for most selfies. However, we should not forget about the equally common type of selfie-a picture in the reflection in the mirror, in which the natural proportions can be preserved, all the limbs could be present. It is also worth noting the inconsistency of the thesis about the indispensable goal of eroticizing one's own picture and the increase in individual body parts as a sign of pursuing this goal: the motive and purpose of a selfie can often be exposed thanks to a comment and an array of hashtags (the exact keyword that regulates the topic of the posted post), revealing the message of the author of the photo. It is equally important to question the thesis of narcissism syndrome and the formation of selfie addiction.

Thus, we can say that social networks today are becoming a space for the construction of personality. Identity can be defined through identification, belonging to a particular social group, and defining boundaries: thus, in the network, the construction of network identity is represented as the construction of the boundaries of the network Self. The network personality, thus, will eventually be built depending on the selected boundaries: age, gender, and professional, social, sexual. This digital identity appears as a zone of self-presentation practices, equal to the boundaries of the selected social meanings in the network. At the same time, it exists, as something permanently created, actualized, like any social construct. Social networks have a diverse and variable potential of social meanings that can make possible various practices of self-presentation through symbolic signification. For most users of social networks, the offline social reality and the digital social reality, therefore, represent a single field of personal existence.

\section{Discussions}

Therefore, today we can say that the body is considered as one of the most important projects of the individual's personality and identity, an instrument for demonstrating intentions and social achievements. The perception of the body directly depends on what cultural and social norms determine it: for example, in societies where Western culture and aesthetics are predominant, negative stereotypes have become established about fullness, which has become associated with laziness, stupidity and weak will, while in the non-Western world, fullness continues to represent health and prosperity, and thinness - poverty and lack of food and means. It is worth noting that the body for its carrier is the very first, familiar and natural object of transformation. For example, in recent decades, once-eccentric body manipulation practices, such as gender reassignment, have become increasingly common and unsurprising. For some, the bodily project never becomes final; the body turns into an object of permanent improvement, which has no result, but only a set of intermediate ones. An insufficiently flexible body that does not meet social demands can serve as a basis for social discrimination. In a society of control, the body becomes not only an individual project, but also a kind of personal indicator that can be calculated.

Thus, today we can say that the body has long penetrated into the digital space and has taken root in it. Undoubtedly, its presence in the network is, nevertheless, specific. The principle of complementarity, which has come to play an important role in modern scientific discourse, has gone beyond the scope of quantum mechanics and has become a general methodological one.

\section{Conclusions}

Thus, there is a constant presentation of your own body in modern Western culture; attention is focused on the value-relevant and most relevant aspects in each specific situation. 
The practice of selfies is a way of constructing a digital identity. Self-identification is based on how the body is evaluated, not on what it is. In non-physical communication, there are simply no non-physical ways of self-representation, since the body shell itself is already of historical value at the deepest genetic level of perception. Even in digital reality, a person is not able to give up his/her corporeality, replacing it only with digital correlations or the construction of a new corporeality.

The study revealed a number of fundamental principles: evaluation, in the form of likes, and feedback, in the form of comments, are the main channel of control over the body; control channels conditionally include internal and external control subjects. Internal internalized norms and ideals of corporeality systematically are represented in all possible media channels. External-the public, which includes the circles of trust and the external circles of users who evaluate the profile.

The body has become a carrier of meaning and a platform for communication with feedback, and the Internet, which has become the main repository of global data sets, has assumed the role of this communication control over the body.

In understanding the essence of the selfie phenomenon, there are two points of view: the selfie, as a continuation of the tradition of self-portrait, and the selfie, as a special unique phenomenon associated more with network media content.

The obvious motive for self-presentation is the desire to be socially approved, to get the highest rating and the most flattering or loud comment. An important motive for designing a selfie is the user's need for a certain visual statement, self-expression. When making selfies, the user is often guided by fashion trends and ready-made templates, which means that by regulating the real body in space, a successful representation of the digital body in the network is formed.

\section{References}

Anderson, B. (2001). Imaginary communities. Moscow: Kanon-Press-C.

Andreeva, G.M. (2001). Social Psychology. Moscow: Aspect Press.

Apasova, I.M. (2008). Primeval self-portrait as an intention to self-knowledge. Bulletin of the Tyumen State University, 5, 268-273.

Baranova, E.A., Zheltukhina, M.R., Shnaider, A.A., Zelenskaya, L.L., Shestak, L.A., Redkozubova, E.A., \& Zdanovskaya, L.B. (2020). New Media Business Philosophy in Conditions of Mass Media Convergence. Online Journal of Communication and Media Technologies, 10(4), e202021. https://doi.org/10.30935/ojcmt/8387

Baudrillard, J. (2006). Consumer Society. Moscow: Republic.

Bayanova, A.R., Sivova, I.V., Kamasheva, Y.L., Popova, O.V., Semyanov, E.V., Shagieva, R.V., Yusupov, I.M. (2020). Student online services consumption: Routine practices or mistrust to digital service? Contemporary Educational Technology, 11(1), 47-54.

Berger, P. \& Lukman, T. (1995). Social construction of reality. A treatise on the sociology of Knowledge. Moscow: Medium.

Bezbogova, M.S. (2016). Social networks in the system of social communications. The world of education-education in the world, 4, 259-262.

Bobyreva, E., Zheltukhina, M., Korovina, K., Busygina, M. (2019). Religious values in global communication of modern society: trends in the development and transformation. SHS Web of Conferences, 69, 00021. https://doi.org/10.1051/shsconf/20196900021

Bourdieu, P. (2002). About television and journalism. Moscow: Foundation for Scientific Research "Pragmatics of Culture", Institute of Experimental Sociology.

Castells, M. (2000). Information Age. Moscow: Higher School of Economics.

Cherdymova, E.I. (2016). Ecological consciousness and ecological culture in the model of ecological education. Bulletin of the Saratov State Technical University, 4, 46-53.

Cherdymova, E.I., Ilkevich, T.G., Spirina, E.V., Blinov, L.V., Aliyev, H.K., Kukhtyaeva, E.A. \& Ivanshina, I.A. (2019). Physicality ecology: student attitude to their own body. Ekoloji, 28(107), 4925-4930.

Drozdova, A.V. (2013). Visuality as a formative principle of culture. Problems of the philosophy of culture. Ural State Mining University Publishing House, 7, 154-168 
Geertz, K. (2004). Interpretation of cultures. Moscow: "ROSSPEN".

Glinchikova, A. (2002). Russia and the Information Society. Moscow: AST Publishing House.

Grinkova, E.A. (2015). Selfie-a look at the history of a cultural phenomenon. Modern scientific research and innovation, 1(3). URL: http://web.snauka.ru/issues/2015/01/40930 (date of access: 03.03.2021).

Huntington, S. (2003). The Clash of Civilizations. Moscow: AST Publishing House.

Konfederat, O.V. (2012). Modifications of the self in the screen image and the problem of the photographic self-portrait. Bulletin of the Chelyabinsk State University: Philology. Art Study, 36(290), 82-88.

Labunskaya, V.A. (2010). Visible man as a socio-psychological phenomenon. Social psychology and society, 1, 26-39.

Lacostina, N.V. (2009). Dynamics of life satisfaction because of photo-visualization of life events. Russia Psychological Journal, 6(3), 65-67.

Lipman, U. (2004). Public Opinion. Moscow: Institute of the Public Opinion Foundation.

McLuhan, M. (2007). Understanding media: the external expansion of man. Moscow: Hyperborea, Kuchkovo field.

Pogontseva, D.V. (2013a). Forming an impression by means of virtual communication. Scientific and methodological electronic journal "Concept", 1(17), 135-141.

Pogontseva, D.V. (2013b). Selfie as a modern socio-psychological phenomenon. Scientific and methodological electronic journal "Concept", 12(28), 111-115.

Reznichenko, S.M., Takhumova, O.V., Zaitseva, N.A., Larionova, A.A., Dashkova, E.V., Zotikova, O.N., \& Filatov, V.V. (2018). Methodological aspects of assessing factors affecting the sustainable development of the region. Modern journal of language teaching methods, $8(11), 70-80$.

Savchuk, V.V. (2013). Media-philosophy: an attack of reality. St. Petersburg: Publishing House of the Russian Christian Humanitarian Academy.

Shapinskaya, E.N. (2012). The Image of the other in the texts of culture: the Politics of representation. Moscow: URSS.

Sohan, I.V. (2008). Deformations of everyday life in modern culture. Bulletin of Tomsk State University, 310, 61-65.

Sorokoumova, E.A. \& Cherdymova, E.I. (2020). Study of the relationship between civil identity and environmental attitudes of students. The category of "social" in modern pedagogy and psychology. Materials of the 8th All-Russian scientific and practical conference with remote and international participation (pp. 493-496). Ulyanovsk: Scientific and Educational Center "Perspektiva".

Sorokoumova, E.A., Cherdymova, E.I., Shulga, T.I., Suvorova, O.V. \& Kochneva, L.V. (2020). Social representations of the metropolis residents on the ecology of women's corporeality in the structure of civil identity. EurAsian Journal of BioSciences, 14(1), 587-592.

Surova, E.E. (2010). Identity. Identification. Image. St. Petersburg, Perspektiva.

Veretekhina, S.V., Shinkareva, O.V., Kozhaev, J.P., Telepchenkova, N.V., Kuznetsova, E.A., \& Zaitseva, N.A. (2017.) Evaluation methodology of the multiplier effect for the region as the result of the cluster formation. Eurasian journal of analytical chemistry, 12(5B), 533-547. 